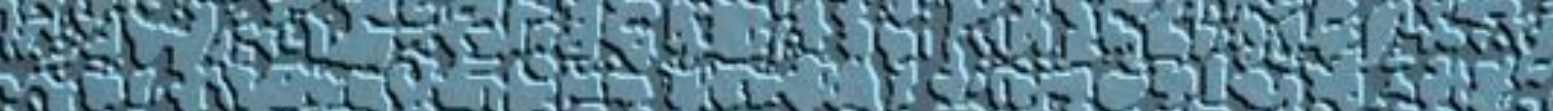

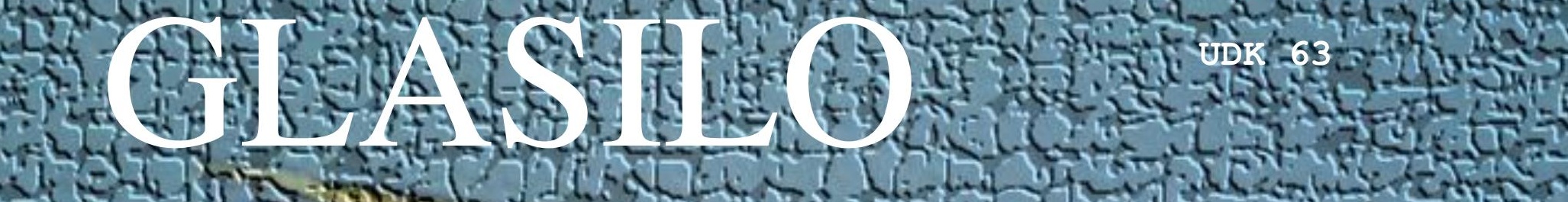

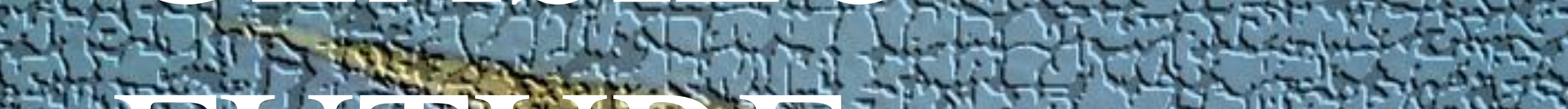
Ant

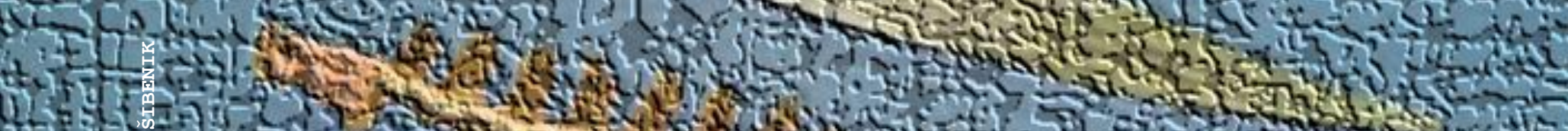

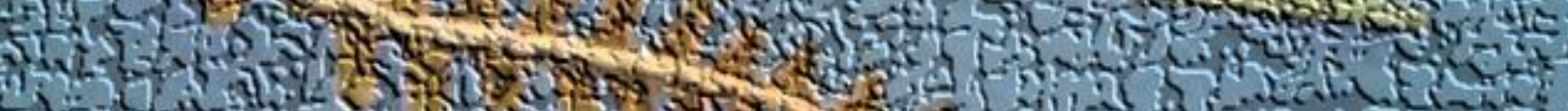
If

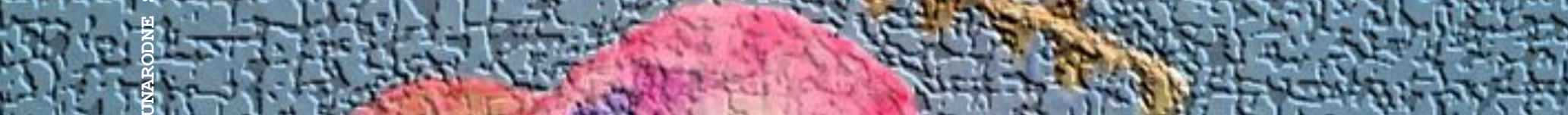

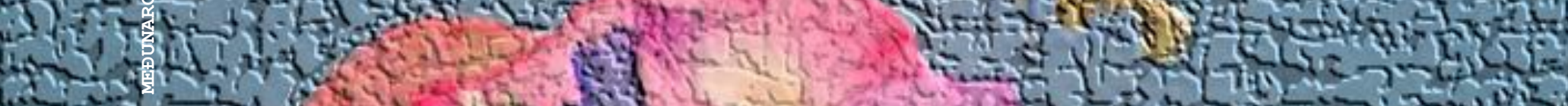

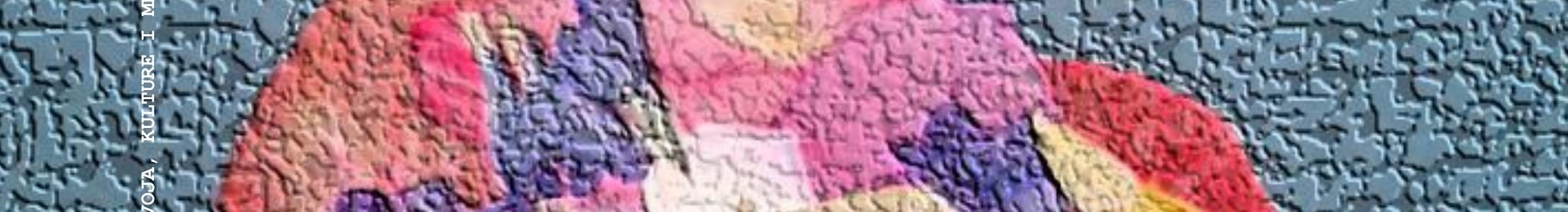
Nog

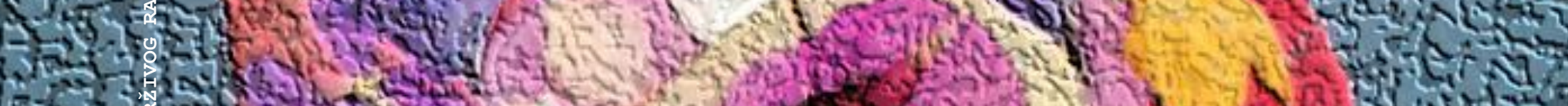

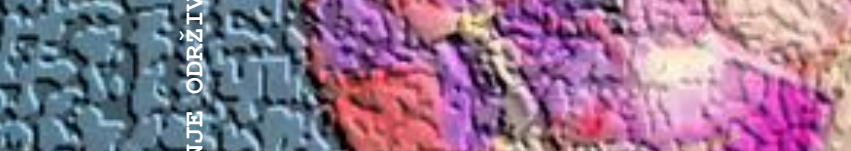
20. S. (2) (1)

1. (c) -

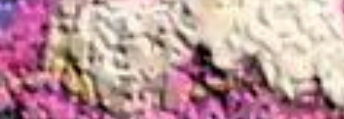
(3)

-1.

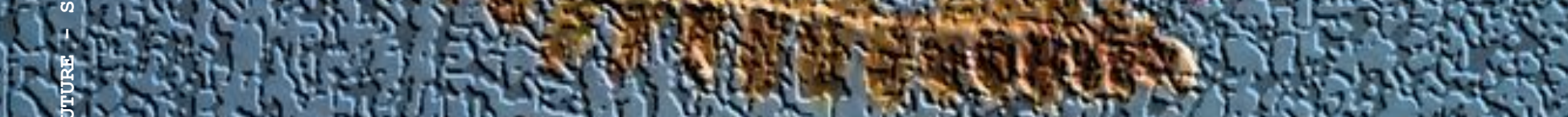
(n) So

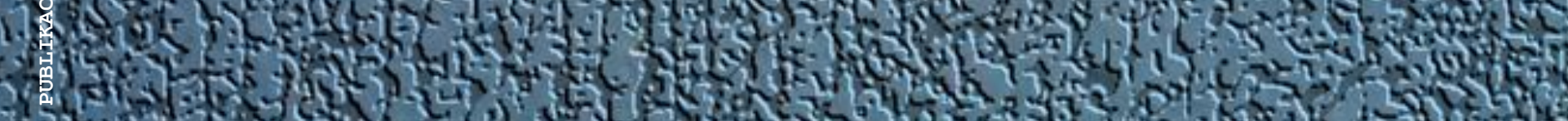
VoIUMgN 4 BRo $2-3$.

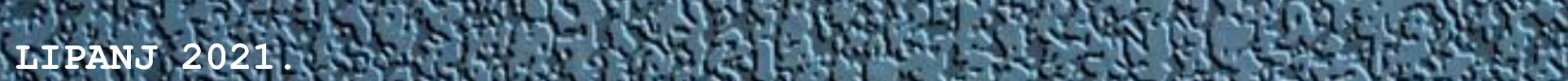

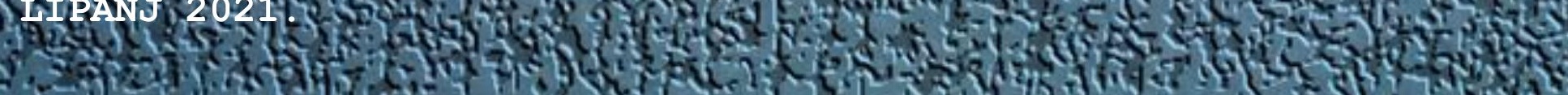




\section{Glasilo Future}

\section{Stručno-znanstveni časopis}

\section{Nakladnik: FUTURA}

\section{$F_{0 T} T_{0 R} A$}

Sjedište udruge: Šibenik
Adresa uredništva:

Bana Josipa Jelačića 13 a, 22000 Šibenik, Hrvatska / Croatia

㞗 / 息: +385 (0) 022218133

凹: urednistvo@gazette-future.eu / editors@gazette-future.eu

(3): www.gazette-future.eu

\section{Uređivački odbor / Editorial Board:}

Doc. dr. sc. Boris Dorbić, v. pred. - glavni i odgovorni urednik / Editor-in-Chief

Emilija Friganović, dipl. ing. preh. teh., v. pred. - zamjenica g. i o. urednika / Deputy Editor-in-Chief

Ančica Sečan, mag. act. soc. - tehnička urednica / Technical Editor

Antonia Dorbić, mag. art. - zamjenica tehničke urednice / Deputy Technical Editor

Prof. dr. sc. Željko Španjol

Mr. sc. Milivoj Blažević

Vesna Štibrić, dipl. ing. preh. teh.

Međunarodno uredništvo / International Editorial Board:

Prof. dr. sc. Kiril Bahcevandziev - Portugalska Republika (Instituto Politécnico de Coimbra)

Prof. dr. sc. Martin Bobinac - Republika Srbija (Šumarski fakultet Beograd)

Prof. dr. sc. Zvezda Bogevska - Republika Sjeverna Makedonija (Fakultet za zemjodelski nauki i hrana Skopje)

Dario Bognolo, mag. ing. - Republika Hrvatska (Veleučilište u Rijeci)

Prof. dr. sc. Agata Cieszewska - Republika Poljska (Szkoła Główna Gospodarstwa Wiejskiego w Warszawie)

Dr. sc. Bogdan Cvjetković, prof. emeritus - Republika Hrvatska (Agronomski fakultet Zagreb)

Prof. dr. sc. Duška Curić - Republika Hrvatska (Prehrambeno-biotehnološki fakultet Zagreb)

Prof. dr. sc. Margarita Davitkovska - Republika Sjeverna Makedonija (Fakultet za zemjodelski nauki i hrana Skopje)

Prof. dr. sc. Dubravka Dujmović Purgar - Republika Hrvatska (Agronomski fakultet Zagreb)

Prof. dr. sc. Josipa Giljanović - Republika Hrvatska (Kemijsko-tehnološki fakultet u Splitu)

Prof. dr. sc. Semina Hadžiabulić - Bosna i Hercegovina (Agromediteranski fakultet Mostar)

Prof. dr. sc. Péter Honfi - Mađarska (Faculty of Horticultural Science Budapest)

Prof. dr. sc. Mladen Ivić - Bosna i Hercegovina (Univerzitet PIM)

Doc. dr. sc. Anna Jakubczak - Republika Poljska (Uniwersytet Technologiczno-Przyrodniczy w Bydgoszczy)

Doc. dr. sc. Orhan Jašić - Bosna i Hercegovina (Filozofski fakultet Tuzla)

Prof. dr. sc. Tajana Krička - Republika Hrvatska(Agronomski fakultet Zagreb)

Doc. dr. sc. Dejan Kojić - Bosna i Hercegovina (Univerzitet PIM)

Slobodan Kulić, mag. iur. - Republika Srbija (Srpska ornitološka federacija i Confederation ornitologique mondiale)

Prof. dr. sc. Biljana Lazović - Crna Gora (Biotehnički fakultet Podgorica)

Prof. dr. sc. Branka Ljevnaić-Mašić - Republika Srbija (Poljoprivredni fakultet Univerziteta u Novom Sadu)

Doc. dr. sc. Zvonimir Marijanović - Republika Hrvatska (Kemijsko-tehnološki fakultet u Splitu)

Doc. dr. sc. Ana Matin - Republika Hrvatska (Agronomski fakultet Zagreb)

Prof. dr. sc. Bosiljka Mustać - Republika Hrvatska (Sveučilište u Zadru)

Hrv. akademik prof. dr. sc. Stanislav Nakić - Bosna i Hercegovina (Sveučilište Hercegovina Mostar)

Prof. dr. sc. Ayșe Nilgün Atay - Republika Turska (Mehmet Akif Ersoy University - Burdur, Food Agriculture and Livestock School) Prof. dr. sc. Tatjana Prebeg - Republika Hrvatska (Agronomski fakultet Zagreb)

Prof. dr. sc. Bojan Simovski - Republika Sjeverna Makedonija (Fakultet za šumarski nauki, pejzažna arhitektura i ekoinženering "Hans Em" Skopje)

Prof. dr. sc. Davor Skejić - Republika Hrvatska (Građevinski fakultet Zagreb)

Akademik prof. dr. sc. Mirko Smoljić, prof. v. š. - Republika Hrvatska (Sveučilište Sjever, Varaždin/Koprivnica, Odjel ekonomije)

Prof. dr. sc. Nina Šajna - Republika Slovenija (Fakulteta za naravoslovje in matematiko)

Dr. Marko Šare - Republika Italija (Hrvatska zajednica u Trstu)

Akademik prof. dr. sc. Refik Šećibović - Bosna i Hercegovina (Visoka škola za turizam i menadžment Konjic)

Prof. dr. sc. Andrej Šušek - Republika Slovenija (Fakulteta za kmetijstvo in biosistemske vede Maribor)

Prof. dr. sc. Elma Temim - Bosna i Hercegovina (Agromediteranski fakultet Mostar)

Mr. sc. Merima Toromanović - Bosna i Hercegovina (Biotehnički fakultet Univerziteta u Bihaću)

Prof. dr. sc. Marko Turk - Ruska Federacija (University of Tyumen)

Doc. dr. sc. Ivana Vitasović Kosić - Republika Hrvatska (Agronomski fakultet Zagreb)

Doc. dr. sc. Ana Vujošević - Republika Srbija (Poljoprivredni fakultet Beograd)

Sandra Vuković, mag. ing. - Republika Srbija (Poljoprivredni fakultet Beograd)

Prof. dr. sc. Vesna Židovec - Republika Hrvatska (Agronomski fakultet Zagreb)

Grafička priprema: Ančica Sečan, mag. act. soc.

Objavljeno: 30. lipnja 2021. godine.

Časopis izlazi u elektroničkom izdanju dva puta godišnje, krajem lipnja i prosinca, a predviđena su i dva specijalna izdanja tijekom godine iz biotehničkog područja.

Časopis je besplatan. Rukopisi i recenzije se ne vraćaju i ne honoriraju.

Autori/ce su u potpunosti odgovorni/e za sadržaj, kontakt podatke i točnost engleskog jezika.

Umnožavanje (reproduciranje), stavljanje u promet (distribuiranje), priopćavanje javnosti, stavljanje na raspolaganje javnosti odnosno prerada u bilo kojem obliku nije dopuštena bez pismenog dopuštenja Nakladnika.

Sadržaj objavljen u Glasilu Future može se slobodno koristiti u osobne i obrazovne svrhe uz obvezno navođenje izvora. 


\section{Glasilo Future}

\section{Stručno-znanstveni časopis}

FUTURA - stručno-znanstvena udruga za promicanje održivog razvoja, kulture i međunarodne suradnje, Bana Josipa Jelačića 13 a, 22000 Šibenik, Hrvatska

(2021) 4 (2-3) 01-85

\section{SADRŽAJ:}

Izvorni znanstveni rad (original scientific paper)

Str.

E. Delić, B. Dorbić, Alisa Adžemović

Dendroflora Donatim parka u Adapazariju/Sakarija - Republika Turska

Dendroflora of Donatım park in Adapazari/Sakarya - Republic of Turkey

\section{Pregledni rad (scientific review)}

Tatjana Prebeg, Kristina Balen, Vesna Židovec

Utjecaj anatomske građe latica na ukrasna svojstva cvjetova

The influence of petal anatomy on ornamental attributes of flowers

Jelica Galić

Značaj proučavanja stanovništva u cilju razvoja poljoprivrede - studija slučaja Županije

Zapadnohercegovačke

The importance of population studies for agricultural development - case study of the West

Herzegovina County

\section{Stručni rad (professional paper)}

D. Krstonošić, Franciska Erdelj, Ž. Škvorc, K. Sever

Odabir autohtonih aromatičnih i ljekovitih trajnica za uređenje terapijskih urbanih prostora na Mediteranu

Selection of autochthonous aromatic and medicinal perennials for therapeutic urban spaces in the Mediterranean

Dubravka Dujmović Purgar, Mateja Palčić, Klara Barić, D. Jareš, Z. Svečnjak Agronomska i gospodarska vrijednost facelije Agronomic and economic value of phacelia

\section{Nekategorizirani rad (uncategorised paper)}

B. Dorbić

Društvene vijesti i obavijesti

Social news and announcements

Zdenka Bilušić, B. Dorbić

Prikaz radionice

Review of workshop 
E. Delić, B. Dorbić, Alisa Adžemović / Dendroflora Donatim parka u Adapazariju/Sakarija Republika Turska / Glasilo Future (2021) 4 (2-3) 01-15

\title{
Dendroflora Donatim parka u Adapazariju/Sakarija - Republika Turska
}

\section{Dendroflora of Donatım park in Adapazari/Sakarya - Republic of Turkey}

\author{
Emir Delić $^{1 *}$, Boris Dorbić ${ }^{2}$, Alisa Adžemović ${ }^{3}$ \\ izvorni znanstveni rad (original scientific paper)
}

doi: $10.32779 /$ gf.4.2-3.1

Citiranje/Citation $^{4}$

\section{Sažetak}

U radu su prikazani rezultati istraživanja dendroflore Donatim parka, koji se nalazi u gradu Adapazari, administrativnom centru i najvećem gradu turske provincije Sakarija, na nadmorskoj visini od $31 \mathrm{~m}$. Tijekom florističkog istraživanja koje je provedeno na obuhvatnom području Donatım parka tijekom prve polovine 2021. godine zabilježeno je 61 svojte iz 28 porodica. U ovom parku dominiraju kritosjemenjače (52 svojte; 85,25 \%), među kojima su dvosupnice (47 svojti; 90,38 \%), izrazito zastupljenije nego jednosupnice. Golosjemenjače su zastupljene s manjim brojem, 9 svojti (14,75\%). Porodica Rosaceae (12 svojti; 19,67\%) i porodica Pinaceae (6 svojti; 9,84 \%) se ističu s najvećim brojem svojti. U pogledu analize flore obzirom na tip habitusa rezultati su pokazali dominaciju stabala (37 svojte; 60,66 \%), potom slijede grmovi (23 svojti; 37,70 \%) te penjačice (1 svojta: 1,64 \%). Listopadne svojte $(36 ; 59,02 \%)$ su zastupljenije od vazdazelenih $(25 ; 40,98 \%)$.

Od 61 zabilježenih svojti, kultivarima pripada 8 svojti $(13,11 \%)$, hibridima dvije $(3,28 \%)$, dok podvrstama pripadaju tri svojte $(4,92 \%)$.

S gledišta krajobraznih vrijednosti Donatim park prilično je bogat dendrološkim svojtama. Drveće i grmlje uglavnom ima izvrsne funkcionalne, estetske i oblikovne karakteristike, osim nekoliko stabala datulje Phoenix dactylifera L. koja su osušena te ih je potrebno ukloniti. Parkovna infrastruktura je u odličnom stanju.

Ključne riječi: dendroflora, inventarizacija, opis stanja, Donatim park, Adapazari-Turska.

\footnotetext{
${ }^{1}$ Šumarski fakultet, Univerzitet u Banjoj Luci, Vojvode Stepe Stepanovića 75a, 78000 Banja Luka. Bosna i Hercegovina, Republika Srpska.

* E-mail: emir.delicc@outlook.com (student diplomskog sveučilišnog studija).

${ }^{2}$ Veleučilište "Marko Marulić" u Kninu, Krešimirova 30, 22300 Knin, Republika Hrvatska.

${ }^{3}$ Univerzitet u Sarajevu, Prirodno-matematički fakultet Sarajevo, Zmaja od Bosne 33-35, 71000, Bosna i Hercegovina (studentica preddiplomskog sveučilišnog studija).

${ }^{4}$ Delić, E., Dorbić, B., Adžemović, A. (2021). Dendroflora Donatim parka u Adapazariju/Sakarija - Republika Turska. Glasilo Future, 4(2-3), 01-15. / Delić, E., Dorbić, B., Adžemović, A. (2021). Dendroflora of Donatım park in Adapazari/Sakarya - Republic of Turkey. Glasilo Future, 4(2-3), 01-15.
} 


\section{Abstract}

In the paper are presented the results of a research done on the dendroflora of Donatim Park that is located in the city of Adapazari, the administrative centre and the largest city of the Turkish Sakarya province, at an altitude of $31 \mathrm{~m}$. During the floristic research that was conducted during the first half of 2021, it has been noted the 61 taxa of plants from the 28 families. The Park is dominated by angiosperms (total of 52 taxa; 85,25 \%), among which dicotyledons (47 taxa; 90,38 \%) are significantly more represented than monocotyledons. Gymnosperms are represented with a smaller number, with total of 9 taxa $(14,75 \%)$. Both of the Rosaceae family (12 taxa; 19,67\%) and the Pinaceae family (6 taxa; 9,84 \%) stand out with the largest number of taxa, respectively. With regards to flora analysis with the respect to habitus type, the results showed the dominance of trees (37 taxa; $60,66 \%)$ that are followed by the shrubs (23 taxa; 37,70 \%) and climbers (1 taxa: 1,64 \%). Deciduous $\operatorname{taxa}(36 ; 59,02 \%)$ are more represented than evergreens $(25 ; 40,98 \%)$.

Of the 61 recorded taxa, 8 taxa $(13,11 \%)$ belong to cultivars, two $(3,28 \%)$ to hybrids, while the three taxa $(4,92 \%)$ belong to the subspecies.

Donatim Park is quite rich in dendrological taxa from the values of the landscape point of view. Trees and shrubs give an excellent functional, aesthetic and shape characteristics, with the exception of a few date palms, Phoenix dactylifera L., which have been dried out and they need to be removed. The Park infrastructure is in excellent condition.

Key words: dendroflora, inventory, state description, Donatim Park, Adapazari-Turkey.

\section{Uvod}

Pokrajina Sakarija zauzima 0,62 \% teritorija Republike Turske. Graniči s pokrajinom Düzce na istoku i Bilecik na jugu, Kocaeli na zapadu i Crnim morem na sjeveru (SBB, 2015., prema, Çinar et al., 2018). Sakarija ima kišovitu, vlažnu i blagu klimu. Prosječna godišnja temperatura iznosi $14,4^{\circ} \mathrm{C}$. Najniža temperatura je $-14,5^{\circ} \mathrm{C}$, a najviša $41,8^{\circ} \mathrm{C}$. Prosječna godišnja vlažnost zraka je $73,9 \%$, a prosječna godišnja količina oborina iznosi $1.016 \mathrm{~mm}$. Prema Köppenovoj klimatskoj klasifikaciji, pokrajina pripada klasi "tople zime te suhog i toplog ljeta" (UNDP., prema, Çinar et al., 2018). Glavni grad pokrajine Sakarije je Adapazari. Područje obiluje s dubokim aluvijalnim tlima i rijekama koje je vrlo povoljno za poljoprivredu. Gospodarstvo je bazirano na modernoj sofisticiranoj industriji. Cijela pokrajina leži na tlu koje je veoma sklono potresima. Nakon razornog potresa iz 1999. godine stambena naselja su formirana sjeverno od grada. Novo formirani stambeni blokovi imaju veliku količinu zelenih površina (Gedikli, 2004).

Vruća i sušna ljeta izrazito su nepovoljna za urbanu floru i na području istraživanja. Zbog visokih temperatura i niske relativne vlage zraka prekidaju se fiziološki procesi u biljci, što dovodi do 
djelomičnog ili potpunog sušenja. Na jesen prve kiše aktiviraju procese kod biljaka te omogućavaju obnovu vegetacije (Čurović et al., 2003). Upravo zbog navedenog na zelenim površinama potrebno je korisiti i autohtone drvenaste vrste koje su bolje prilagođene na lokalne ekološke uvjete (Čurović et al., 2003; Dorbić i Temim, 2018; Löki et al., 2019; Tafra et al., 2012).

Parkovi i javni otvoreni prostori koriste se za pasivnu i aktivnu rekreaciju. Oni se razlikuju u veličini, obliku i funkciji koju obavljaju. Za procjenu potreba zajednice potrebno je postaviti strateški pristup i planirati dodatnu izgradnju zelene gradske mreže. Pozitivan utjecaj biljaka na zrak, tlo i mikroklimu neprocjenjiv je za urbano okruženje (Sandeva et al., 2013).

Urbane zelene površine u pokrajini Sakariji (urbani parkovi, gradski trgovi, kružni tokovi) zauzimaju površinu od 4.553.171,65 $\mathrm{m}^{2}$. Površina urbanog zelenila koje se nalazi uz kružne tokove i ceste iznosi $555.111,74 \mathrm{~m}^{2}$. Prema pravilu o zoniranju teritorija količina zelenih površina po stanovniku trebala bi biti $10 \mathrm{~m}^{2}$, ali za Sakariju imamo iznos od $4,66 \mathrm{~m}^{2}$ po stanovniku (Çinar et al., 2018).

Park Donatim je jedan od značajnijih gradskih parkova Adapazarija, a nalazi se pored sportske dvorane Atatürk. Park odiše suvremenim dizajnom, a nedavno su završeni radovi i na obnovi novih igrališta, košarkaških terena i prostora za sjedenje (https://www.sakarya.bel.tr/tr/Haber/donatim-parkyeni-yuzune-kavustu/8700). U parku prevladavaju stabla, od kojih se najviše ističu drvoredi Fraxinus angustifolia Vahl. subsp. oxycarpa (poljski jasen) drvoredi Platanus orientalis L. (istočnjačke platane) i Acer negundo L. (negundovca).

Parkovi i zelene površine su značajni i zbog očuvanja biološke raznolikosti. Npr. intenzivna urbanizacija Istanbula kao odgovor na brzu populaciju smanjila je broj i veličinu zelenih površina. Stoga su sve vrste zelenih površina izuzetno značajne u smislu očuvanja urbane biološke raznolikosti (Çoban et al., 2021). Prema istraživanjima Çoban et al. (2021), botanički vrtovi su imali najveću raznolikost, a slijedili su ih vrtovi. Stambena područja pokazala su se značajnima u pogledu grmlja (52 $\%)$ i zimzelenih vrsta (58 \%), koje su uglavnom egzote $(71 \%)$. Većina vrsta drveća korištenih u javnim zelenim površinama Istanbula uglavnom je istovjetna vrstama koje se koriste u europskim gradovima. Parkovna dendroflora na području ovog dijela Turske nije odveć istraživana, stoga ovo istraživanje daje značajan prilog poznavanju ukrasnog drveća i grmlja u urbanim gradskim zonama mediteranskog dijela Turske.

\section{Materijali i metode}

U radu je inventarizirana dendroflora na području Donatım parka, koji se nalazi u gradu Adapazari. Tijekom terenskih istraživanja od ožujka do lipnja mjeseca 2021. godine inventarizirana je 61 dendrološka svojta. Istraživanja su se zasnivala na obilasku terena, opisivanju istraživane površine metodom promatranja i inventarizaciji dendroflore. Donatim park izgrađen je na starom zemljištu, 
nekadašnje ruševne "poljoprivredne tvornice" na površini od $160.000 \mathrm{~m}^{2}$. Prostor za rekreaciju sadržava $4500 \mathrm{~m}^{2}$. Unutar parka nalazi se i umjetno jezero od $14.000 \mathrm{~m}^{2}$, a okružen je umjetnim kanalom "Çark creek", koji prolazi kroz grad Adapazari. Potonje je nastalo ispuštanjem vode iz obližnjeg Sapanca jezera. Park privlači pažnju brojnih ljudi koji žive u okolnim pokrajinama, posebno Istanbulu (https://www.sozcu.com.tr/hayatim/seyahat/sakaryanin-incisi-donatim-park/) (Slike 1 i 2).

U središtu parka se nalazi veliko umjetno jezero oko kojeg se nalazi mali umjetno izrađeni otok. S desne strane jezera formirana je šetnica koja ga i okružuje. Pored šetnice su zasađeni brojni ukrasni grmovi i aleje sa stablima. S lijeve strane jezera nalazi se restoran i rekreacijske zone. Na kraju šetnice, s druge strane jezera uočen je putnički zrakoplov koji ima dekorativnu funkciju u prostoru. Unutar parka je izgrađena i džamija.

Za determinaciju biljnih vrsta korištena je sljedeća floristička literatura: Domac, 1994; Erhardt et al., 2002; Franjić i Škvorc, 2010; Idžojtić, 2005; Idžojtić, 2009; Idžojtić, 2013; Idžojtić, 2019; Jovanović, 1985; Russell, 2003; Šilić, 1990, 2005; Tutin et al., 1964-1980; Vidaković i Franjić, 2004; Walters et al., 1984-1986; Walters et al., 1989.

Nomenklatura svojti u popisu flore usklađena je prvenstveno prema Nikoliću, 2021 te prema Borzan, 2001; Idžojtić; 2009; Vidaković i Franjić 2004. Hrvatski nazivi svojti dani su prema: Borzan, 2001; Domac, 1994; Vidaković i Franjić, 2004; Idžojtić, 2009.

U danom popisu flore, vrste, podvrste i kultivari su navedeni abecednim redom u okviru porodica i viših sistematskih kategorija. Za svaku svojtu navedeno je sljedeće: znanstveno i hrvatsko ime, oblik habitusa te podaci je li je vrsta listopadna ili vazdazelena. Razdioba životnih oblika dana je prema Erhardtu et al., 2002 uz određena pojednostavljenja. U popisu flore navode se sljedeće kratice: G-grm, G/S-grm ili stablo, S/G-stablo ili grm, S-stablo, Li-penjačica (lijana). Dok je raspodjela svojti na listopadne (L) i vazdazelene (V) preuzeta iz: Walters, 1986; Walters, 1989; Erhardt et al., 2002.

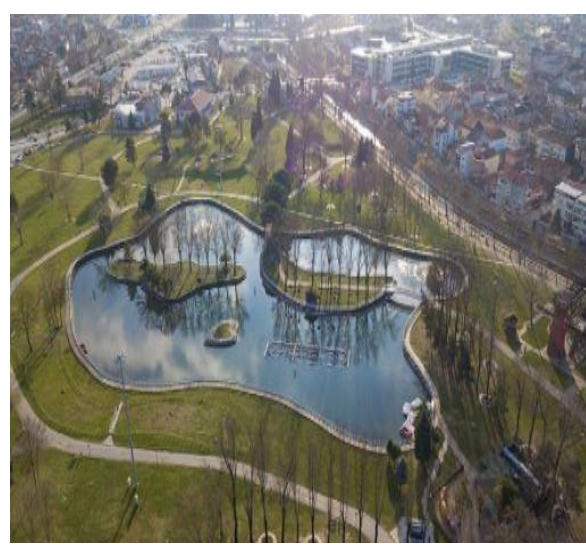

Slika 1. Donatim park (Foto: B. Ulukaya)

Figure1. Donatim park (Photo: B. Ulukaya)

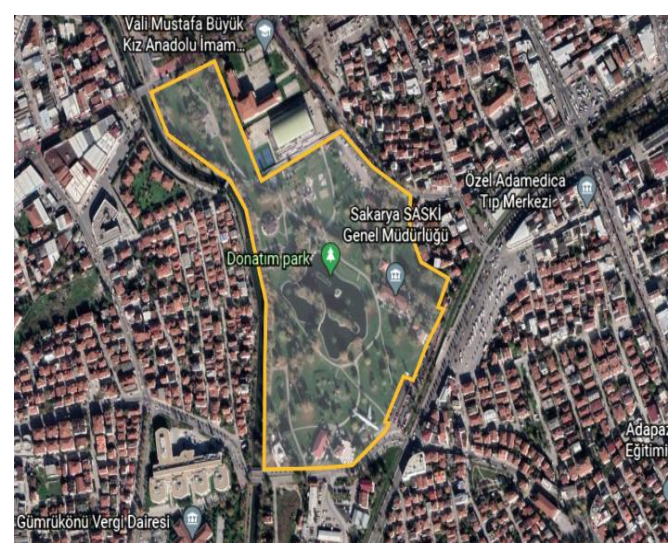

Slika 2. Satelitska snimka istraživanog područja Donatim parka (Izvor: Google maps)

Figure 2. Satellite image of the investigated area in Donatım park (Source: Google maps) 


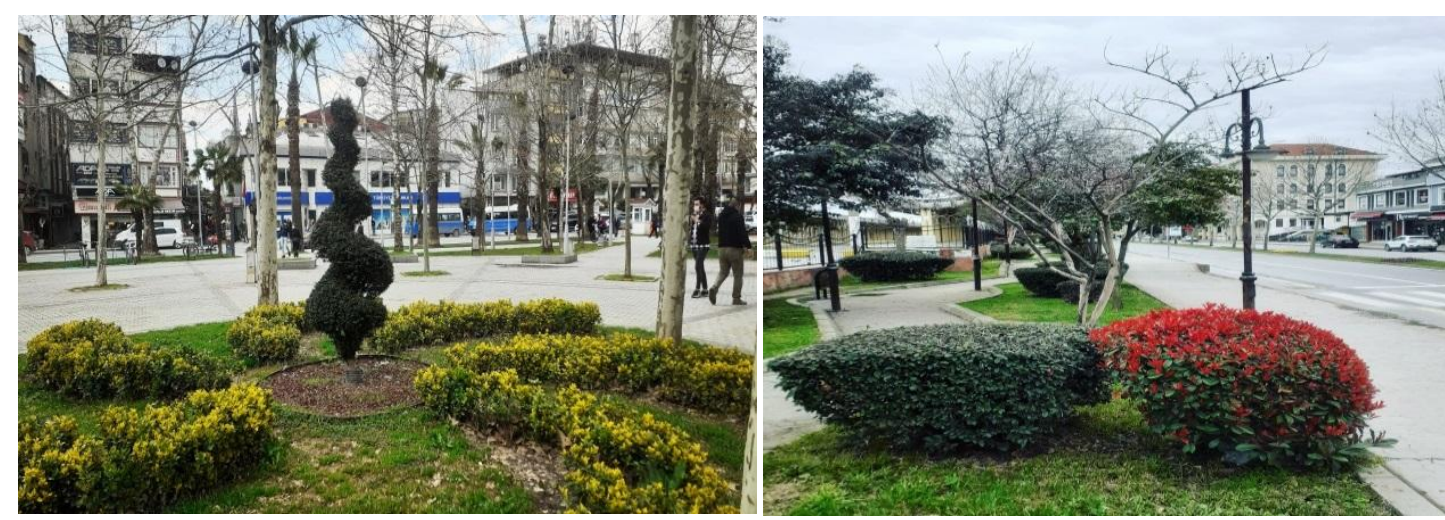

Slika 3. Pogled-2 na gradsko zelenilo Adapazaria (Foto: E. Delić, 2021)

Figure 3. View-2 at city greenery of Adapazari (Photo: E. Delić, 2021)

\section{Rezultati i diskusija}

\section{Popis flore}

Popis dendroflore Donatım parka u gradu Adapazari dan je u tablici 1. Dendroflora u parku je determinirana do razine kultivara s ukupno 61 svojti.

Tablica 1. Popis dendroflore u istraživanom području Donatım parka u gradu Adapazari

Table 1. List of dendroflora in the investigation area of Donatım park

\begin{tabular}{|l|l|l|l|}
\hline SPERMATOPHYTA / GYMNOSPERMAE / CONIFEROPSIDA & \multicolumn{3}{|l|}{} \\
\hline Cupressus arizonica Greene (arizonski čempres) & Cupressaceae & S & V \\
\hline Cupressus sempervirens L. (obični čempres) & Cupressaceae & S & V \\
\hline Thuya orientalis L. (istočnjačka tuja) & Cupressaceae & G/S & V \\
\hline Cedrus deodara (Roxb.) G. Don (himalajski cedar) & Pinaceae & S & V \\
\hline Picea abies (L.) H. Karsten (obična smreka) & Pinaceae & S & V \\
\hline Picea pungens Engelm. (bodljikava smreka) & Pinaceae & S & V \\
\hline Pinus nigra J.F. Arnold subsp. Pallasiana (crni bor) & Pinaceae & S & V \\
\hline Pinus pinea L. (pinija) & Pinaceae & S & V \\
\hline Pinus sylvestris L. (bijeli bor) & Pinaceae & S & V \\
\hline ANGIOSPERMAE / MAGNOLIOPSIDA (DYCOTYLEDONES) & & \\
\hline Acer negundo L. (negundovac) & Aceraceae & S & L \\
\hline Acer platanoides 'Crimson King' (dlanastolisni javor) & Aceraceae & S & L \\
\hline Hedera helix L. (obični bršljan) & Araliaceae & Li & V \\
\hline Berberis thunbergii 'Atropurpurea' (Thunbergova žutika) & Berberidaceae & G & L \\
\hline Betula pendula L. (obična breza) & Betulaceae & S & L \\
\hline Corylus avellana L. (obična lijeska) & Betulaceae & G & L \\
\hline
\end{tabular}




\begin{tabular}{|c|c|c|c|}
\hline Catalpa bignonioides Walter (obična katalpa) & Bignoniaceae & S & $\mathrm{L}$ \\
\hline Gleditsia triacanthos 'Sunburst' (gledičija) & Caesalpiniaceae & $\mathrm{S}$ & $\mathrm{L}$ \\
\hline Viburnum rhytidophyllum Hemsl. (kineska hudika) & Caprifoliaceae & $\mathrm{G} / \mathrm{S}$ & V \\
\hline Viburnum tinus L. (lemprika) & Caprifoliaceae & G & $\mathrm{V}$ \\
\hline Euonymus japonica 'Aureomarginatus' (japanska kurika) & Celastraceae & $\mathrm{G} / \mathrm{S}$ & $\mathrm{V}$ \\
\hline Caragana arborescens Lam. (grašolika drvenasta) & Fabaceae & $\mathrm{G} / \mathrm{S}$ & $\mathrm{L}$ \\
\hline Robinia pseudoacacia L. (obični bagrem) & Fabaceae & $\mathrm{S}$ & $\mathrm{L}$ \\
\hline Philadelphus coronarius L. (obični pajasmin) & Hydrangeaceae & $\mathrm{G}$ & $\mathrm{L}$ \\
\hline Juglans regia L. (obični orah) & Juglandaceae & S & $\mathrm{L}$ \\
\hline Laurus nobilis L. (lovor) & Laureaceae & $\mathrm{G} / \mathrm{S}$ & $\mathrm{V}$ \\
\hline Liriodendron tulipifera L. (američki tulipanovac) & Magnoliaceae & S & $\mathrm{L}$ \\
\hline Hibiscus syracus L. (hibiskus) & Malvaceae & G & $\mathrm{L}$ \\
\hline Melia azedarach L. (očenašica) & Meliaceae & S & $\mathrm{L}$ \\
\hline Ficus carica L. (obična smokva) & Moraceae & $\mathrm{S} / \mathrm{G}$ & $\mathrm{L}$ \\
\hline Morus alba L. (bijeli dud) & Moraceae & S & $\mathrm{L}$ \\
\hline Morus alba 'Pendula' (bijeli dud) & Moraceae & $\mathrm{S}$ & $\mathrm{L}$ \\
\hline Fraxinus angustifolia subsp. oxycarpa Bieb ex. Willd (poljski jasen) & Oleaceae & S & $\mathrm{L}$ \\
\hline Olea europaea L. subsp. europaea (maslina) & Oleaceae & $\mathrm{G} / \mathrm{S}$ & $\mathrm{V}$ \\
\hline Syringa vulgaris L. (obični jorgovan) & Oleaceae & $\mathrm{G} / \mathrm{S}$ & $\mathrm{L}$ \\
\hline Platanus orientalis L. (istočnjačka platana) & Platanaceae & $\mathrm{S}$ & $\mathrm{L}$ \\
\hline Punica granatum L. (šipak) & Punicaceae & $\mathrm{G} / \mathrm{S}$ & $\mathrm{L}$ \\
\hline Cotoneaster lacteus W.W. Sm. (bijela mušmulica) & Rosaceae & $\mathrm{G}$ & V \\
\hline Cydonia oblonga Mill. (Obična dunja) & Rosaceae & $\mathrm{G} / \mathrm{S}$ & $\mathrm{L}$ \\
\hline Eriobotrya japonica (Thunb.) Lindl. (japanska nešpula) & Rosaceae & $\mathrm{S} / \mathrm{G}$ & $\mathrm{V}$ \\
\hline Malus $x$ purpurea (Barbier) Rehder (crvena jabuka) & Rosaceae & $\mathrm{S}$ & $\mathrm{L}$ \\
\hline Photinia serratifolia (Desf.) Kalkman (fotinija) & Rosaceae & G & V \\
\hline Prunus avium L. (trešnja) & Rosaceae & $\mathrm{S}$ & $\mathrm{L}$ \\
\hline Prunus cerasifera Ehrh. (mirobalana) & Rosaceae & $\mathrm{G} / \mathrm{S}$ & $\mathrm{L}$ \\
\hline Prunus domestica L. (šljiva) & Rosaceae & $\mathrm{S} / \mathrm{G}$ & $\mathrm{L}$ \\
\hline Prunus cerasifera 'Pissardii' (mirobalana) & Rosaceae & $\mathrm{G} / \mathrm{S}$ & $\mathrm{L}$ \\
\hline Prunus laurocerarus L. (lovorvišnja) & Rosaceae & $\mathrm{S} / \mathrm{G}$ & $\mathrm{L}$ \\
\hline Pyrus communis L. (kruška) & Rosaceae & $\mathrm{S}$ & $\mathrm{L}$ \\
\hline Rosa sp. (ruža) & Rosaceae & $\mathrm{G}$ & $\mathrm{L}$ \\
\hline Populus alba L. (bijela topola) & Salicaceae & $\mathrm{S}$ & $\mathrm{L}$ \\
\hline Populus nigra 'Thevestina' (crna topola) & Salicaceae & S & $\mathrm{L}$ \\
\hline
\end{tabular}




\begin{tabular}{|l|l|l|l|}
\hline Salix alba L. (bijela vrba) & Salicaceae & S & L \\
\hline Salix x sepulcralis Simonk. & Salicaceae & S & L \\
\hline Ailanthus altissima (Mill.) Swingle(žljezdasti pajasen) & Simaroubaceae & S & L \\
\hline Taxus baccata 'Fastigiata' (obična tisa) & Taxaceae & G/S & V \\
\hline Tilia platyphyllos Scop. (velelisna lipa) & Tiliaceae & S & L \\
\hline Tilia tomentosa Moench (srebrnasta lipa) & Tiliaceae & S & L \\
\hline LILIOPSIDA (MONOCOTYLEDONES) & & \\
\hline Agave americana L. (američka agava) & Agavaceae & G & V \\
\hline Yucca gloriosa L. (juka) & Agavaceae & G & V \\
\hline Phoenix dactylifera L. (obični datuljevac) & Arecaceae & G & V \\
\hline Trachycarpus fortunei (Hooker) Wendl. (visoka žumara) & Arecaceae & S & V \\
\hline Washingtonia filifera (Linden) H. Wendl. (vašingtonija) & Arecaceae & S & V \\
\hline
\end{tabular}

\section{Analiza flore}

Tijekom florističkih istraživanja taksonomskom analizom dendroflore Donatım parka u gradu Adapazari (Tablica 1.) obuhvaćena je 61 svojta, unutar 28 porodica. U ovom parku dominiraju kritosjemenjače (52 svojte; 85,25\%), među kojima su dvosupnice (47 svojti; 90,38 \%), zastupljenije nego jednosupnice (5 svojti; 9,62 \%). Golosjemenjače su zastupljene s 9 svojti (14,75\%). I druga istraživanja urbane dendroflore $\mathrm{u}$ drugim mediteranskim i submediteranskim zemljama su utvrdila veću zastupljenost kritosjemenjača u odnosu na golosjemenjače (urbana dendroflora na području Mostara, Šolić (1974); ili npr. na području Rijeke, Karavla (1974). S najvećim brojem svojti ističe se porodica Rosaceae (12 svojti; 19,67 \%) i porodica Pinaceae (6 svojti; 9,84 \%). Slično potonjem navodi i Potapenko et al (2020) za obalne zelene površine na području Krima te Dorbić et al (2014) za dendrofloru odabranih vrtova na području Knina.

U pogledu analize flore obzirom na tip habitusa (Erhardt et al., 2002) rezultati pokazuju dominaciju stabala (37 svojte; 60,66 \%), zatim slijede grmovi (23 svojti; 37,70 \%) i penjačice (1 svojta: 1,64 \%). Dominacija stabala u prostranijim tipovima krajobraznih površina je logična zbog nužne forme i strukture koje daju stabla. Za manje prostore i vrtove više se koriste grmovi (Tafra et al., 2012; Dorbić et al., 2014). Listopadne svojte (36; 59,02 \%) su zastupljenije od vazdazelenih (25; 40,98 \%).

Od 61 zabilježenih svojti, u kultivare spada 8 svojti (13,11\%), u hibride dvije svojte $(3,28 \%)$, dok podvrstama pripadaju tri svojte $(4,92 \%)$. 


\section{Parkovna dendroflora i infrastruktura u oblikovanju Donatım parka u gradu Adapazari-osvrt}

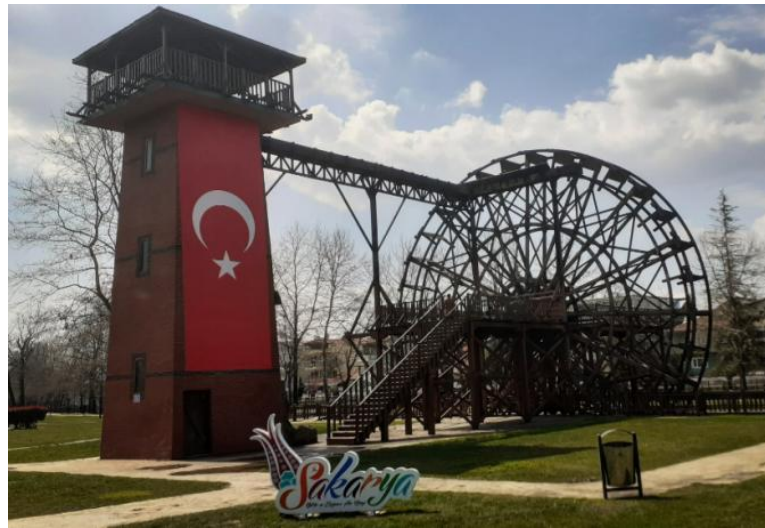

Slika 4. Pogled-1. na Donatım park Figure 4. View-1 at Donatım park (Foto: Emir Delić, 2021) (Foto: Alisa Adžemović, 2021)

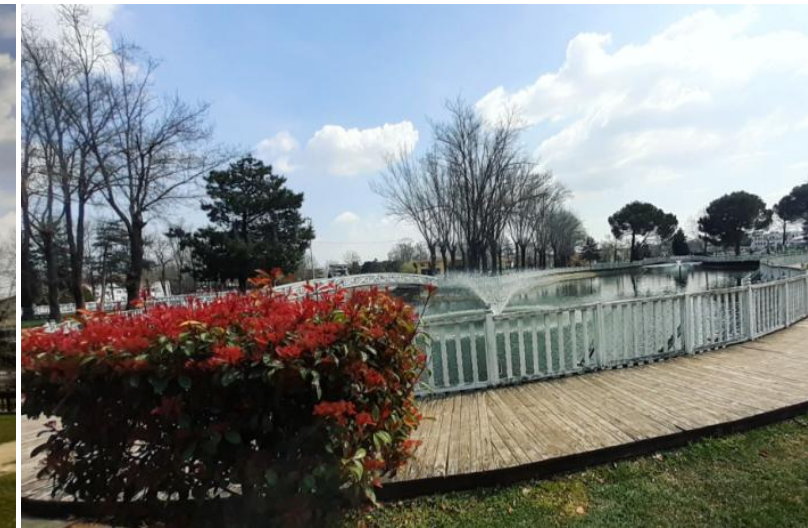

Slika 5. Pogled-2. na Donatım park Figure 5. View-2 at Donatım park (Photo: Emir Delić, 2021) (Photo: Alisa Adžemović, 2021)

Donatim park (Slike 4 i 5) u gradu Adapazari veoma je bogat dendrološkim svojtama. Tijekom terenskog istraživanja utvrđeno je da Donatım park obiluje dendrološkim svojtama, njih čak 61, te se ubraja u jedan od najljepših i najvećih parkova u proviniciji Sakarija. Većina stabala i grmova odličnog su vitaliteta i zadovoljavajućeg estetskog stanja, osim nekoliko stabala Phoenix dactylifera L., (obični datuljevac) koje su se osušile, vjerojatno zbog neodgovarajućih staniših uvjeta (suvišak vode, s obzirom da su posađene neposredno uz umjetno jezero) (Slika 6). Ostala parkovna stabla i grmovi imaju pravilno formiranu (orezanu) i zdravu krošnju, jer se redovito godišnje održavanje parka provodi na vrijeme i prema pravilima struke. Debla stabala su zdrava, bez tragova gljivičnih infekcija. Također, rak rane, i različiti tumori nisu prisutni na stablima. Krošnje su im pravilno formirane. Što se tiče štetne entomofaune, stabla $F$. angustifolia (poljski jasen) su u manjoj mjeri napadnuta ušima Prociphilus fraxinifolli Fabricius koje izazivaju kovrčanje listova i čine im samo estetske štete. Parku je potrebna umjerena revitalizacija u cilju uklanjanja osušenih datulja koje bi se zamijene adekvatnim svojtama. U parku se nalazi veći broj mladih stabala i novih sadnica, koje se estetski odlično uklapaju u već prisutne starije drvorede.

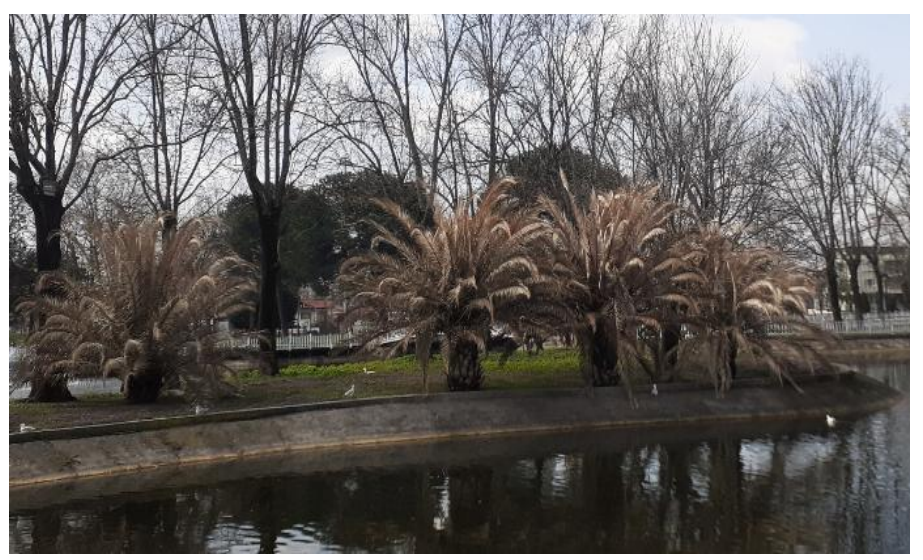

\section{Slika 6.}

Pogled na osušene grmove palme datulje (Foto: E. Delić, 2021)

\section{Figure 6.}

View on dried shrubs of date palm (Photo: E. Delić, 2021) 


\section{Osvrt na podvrste u Donatım parku}

U Donatım parku od ukupno 61 inventariziranih svojti, prisutne su i tri podvrste: poljski jasen (Fraxinus angustifolia subsp. oxycarpa Bieb ex. Willd (poljski jasen), Olea europaea L. subsp. europaea (maslina) i Pinus nigra J.F. Arnold subsp. pallasiana (anadolski crni bor).

\section{Poljski jasen (Fraxinus angustifolia subsp. oxycarpa Bieb ex. Willd)}

Fraxinus angustifolia Vahl (poljski jasen) autohtona je vrsta jasena u Europi. F. angustifolia nalazi se u cijelom južnoj i Istočnoj Europi. Raširen je od Španjolske i Portugala na zapadu, sjeverno do Slovačke i južne Moravske, te istočno do Turske (Mediteran i Crnomorskom području), Siriji, Kavkazu, Iranu i južnoj Rusiji (Fraxigen, 2005). To je listopadna, anemofilna i higrofilna vrsta. Uglavnom se javlja uz riječne tokove jadranskoga sliva kao i u panonskim nizinskim šumama (Anić, 2009., prema, Panjan, 2020). F. angustifolia, uključuje kompleks svojti koje nisu u potpunosti razjašnjene zbog velikih varijacija u morfologija. Poznate su tri geografske podvrste: $F$. angustifolia subsp. angustifolia u jugozapadnoj Europi i sjeverozapadnoj Africi, F. angustifolia subsp. oksikarpa na jugoistoku i srednjoj Europi te F. angustifolia subsp. Syriaca, čiji je areal od Turske do Srednje Azije. Stablo može doseći preko $30 \mathrm{~m}$ visine. Listovi su relativno uski s izrazito nazubljenim ili nazubljenim rubovima. List i izdanci unutar ove tri vrste su vrlo varijabilni (Wallander, 2013). U mediteranskim zemljama s listanjem započinje od sredine ožujka do sredine svibnja i vegetacijski period mu je dulji, a u srednjoj Europi s listanjem počinje od kraja ožujka do sredine svibnja i vegetacijski period je nešto kraći (Fraxigen, 2005). F. angustifolia dobro uspijeva na vlažnim, glinovitim te dobro dreniranim tlima (Fraxigen, 2005). F. angustifolia subsp. oxycarpa Bieb ex. Willd (Slika 7.) porijeklom je iz nizina Marmare i crnomorske regije u Turskoj. Šume su mu oštećene i smanjene, a posebno u nizinama zbog blizine naselja (Çiçek, 2002., prema, Çiçek i Yilmaz., 2002).

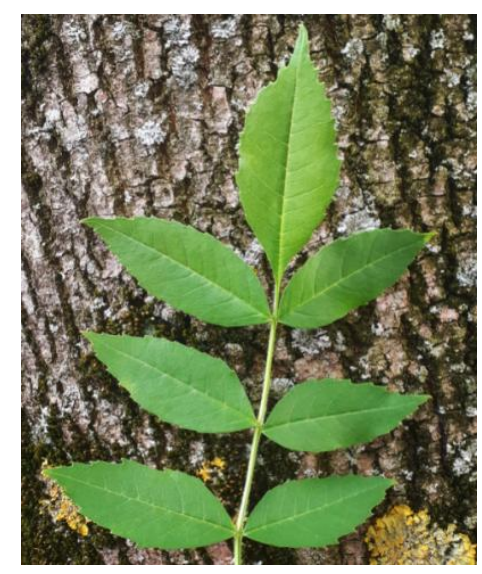

Slika 7. Poljski jasen (Foto: E. Delić, 2021)

Figure 7. Narrow-leaved ash (Photo: E. Delić, 2021) 


\section{Maslina (Olea europaea L. subsp. europaea)}

O. europaea L. (maslina) pripada porodici Oleaceae, rodu Olea. Izgled masline se sastoji od stabla nepravilnog oblika, koje je visoko do $10 \mathrm{~m}$, ukoliko nije u intenzivnom uzgoju. U zreloj dobi karakterizira ga mnoštvo kvrga (Barbarić et al., 2014). Listovi masline su vazdazeleni, tvrdi, kožasti. S gornje strane su tamnozeleni, goli i sjajni, a s donje srebrnastosive boje (Idžojtić, 2009) (slika 8). Plodovi su eliptične ili kuglaste, gole, glatke, tamnoljubičaste-crne koštunice. Plodovi su jestivi. Cvjetovi su joj dvospolni, mirisni i sitni (Idžojtić, 2013). Uzgaja se u dva svjetska pojasa između 30 i $45^{\circ}$ sjeverne i 30 i $45^{\circ}$ južne geografske širine. Najviše se uzgaja u zemljama na području Mediterana. Turska je najveći proizvođač masline u Aziji (Miranović, 2006; FAO).

Maslina se najviše uzgaja u suptropskoj zoni i zahtjeva obilje svjetlosti. U Mediteranskim zemljama visoke temperature ovoj kulturi ponekad nanesu palež lista i ploda. U zimskom razdoblju maslina podnese do $-8^{\circ} \mathrm{C}$, u trajanju od nekoliko dana. Preosjetljiva je na velike količine vode. Najviše joj odgovaraju ocjedita lagana tla (Nikolić i Radulović, 2010).

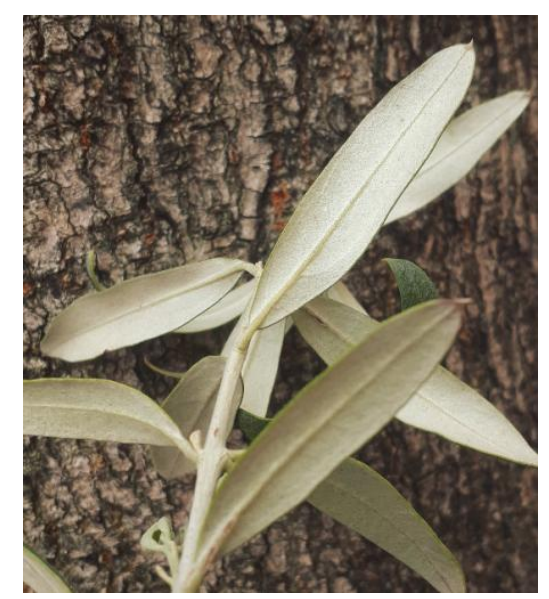

Slika 8. Listovi masline (Foto: E. Delić, 2021)

Figure 8. Olive tree leaves (Photo: E. Delić, 2021)

\section{Anadolski crni bor (Pinus nigra J.F. Arnold subsp. pallasiana)}

Pinus nigra Arnold (europski crni bor) jedan je od vodećih vrsta za pošumljavanje sušnih i stjenovitih terena na području submediterana. Izraziti je heliofit i rasprostranjen je na nadmorskoj visini od 2501400 metara (Vidaković, 1993., prema, Tolun et al., 2000). Europski crni bor je uglavnom južnoeuropska vrsta čiji se areal proteže od Španjolske do Turske. Zbog svoje prirodne rasprostranjenosti, smatra se vrlo promjenjivom vrstom $u$ pogledu morfoloških, anatomskih i fizioloških karakteristika (Scaltsoyiannes et al., 1994., prema, Tolun et al., 2000).

Crni bor može dosegnuti i do $50 \mathrm{~m}$. Ima ravno deblo sa smeđom korom. Pupovi su jajoliki, a iglice, su zelene ili tamnozelene boje. Češeri su sjedeći, 2-4 cm široki, smeđe boje (Vidaković,1993). 
Ovo je vrsta s dekorativnim nadzemnim karakteristikama koja se upotrebljava u submediteranskom području. U krajobrazu se koristi kao soliter, u grupama ili za drvorede, a dobro podnosi i gradske uvjete (Dorbić i Španjol, 2018). Schwarz (1938., prema, Tolun et al., 2000) je crni bor grupirao u šest podvrsta: sub. pallasiana, subs. fenzlii, sub. dalmatica, sub. nigra, sub. laricio i pods. salzmannii. Turska podvrtsta europskog crnog bora, Pinus nigra J.F. Arnold subsp. pallasiana (Anadolski crni bor), raširena je na području planine Taurus, zapadne i sjeverne Anadolije (slika 9). Prema Ata (1995), budući da anatolski crni bor uspješno raste u različitim rasponima provenijencija u prevladavajućim klimatskim uvjetima, ova vrsta se uglavnom uvodi u plantaže čak i u kontinentalnim regijama na stepe.

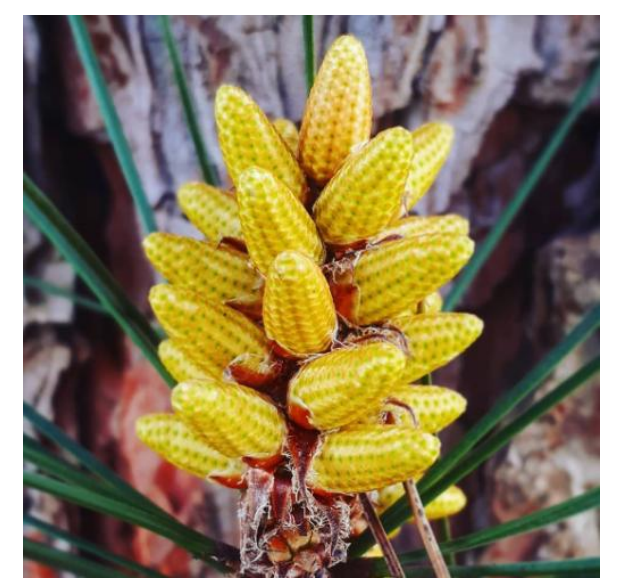

\section{Slika 9.}

Muški cvjetovi anadolskog crnog bora

(Foto: A. Adžemović, 2021).

Figure 9.

Male flowers of Anatolian black pine

(Photo: A. Adžemović, 2021).

\section{Parkovna infrastruktura}

Parkovna infrastruktura (klupe, staze) unutar Donatim parka su u odličnom stanju, bez vidljivih tragova oštećenja. U parku se nalazi i restoran za posjetitelje, a pored klupa za odmor, dekorativnih fontana na jezeru, tu su i montirane različite sprave za vježbanje i rekreaciju u prirodi, kao i uređene biciklističke staze. Navedeno doprinosi velikoj posjećenosti parka u svim sezonama. U parku se nalazi i ogromni model putničkog zrakoplova (Slika 10), u kojem gradonačelnik grada Adapazari planira otvoriti restoran za stanovnike i turiste, kao i stara, dekorativna drvena vjetrenjača (Slika 11).

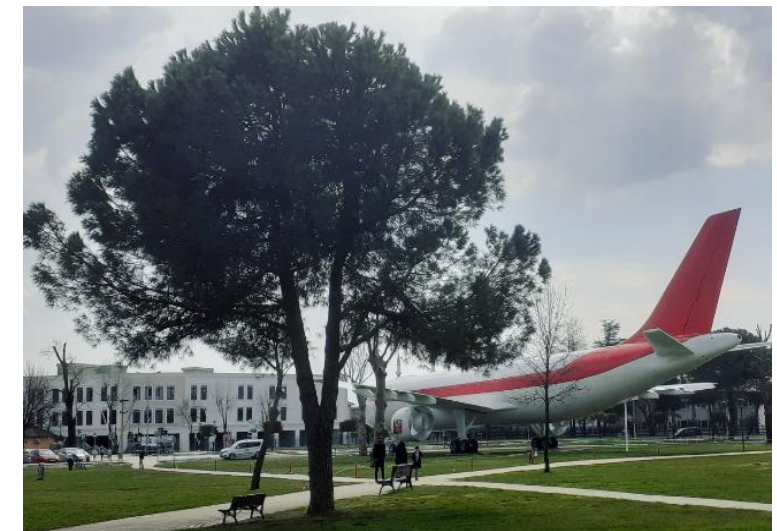

Slika 10. Pogled na zrakoplov u parku Slika 11. Pogled na staru vjetrenjaču (Foto: A. Adžemović, 2021). (Foto: E. Delić, 2021).

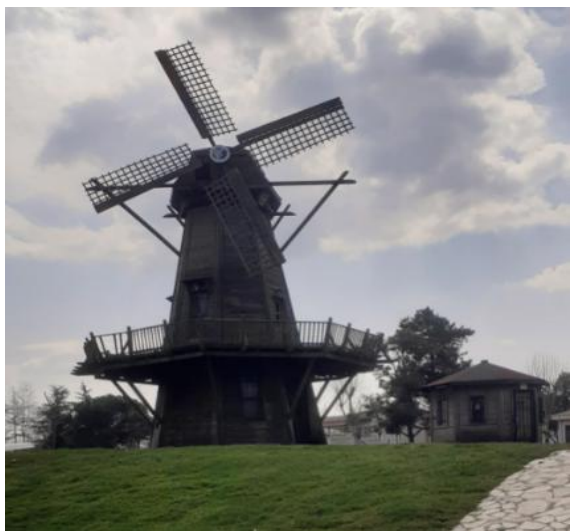

Figure 10. View on airplane in park Figure 11. View on old windmill

(Photo: A. Adžemović, 2021). (Photo: E. Delić, 2021) 


\section{Zaključak}

Tijekom florističkog istraživanja inventarizacije Donatım parka u gradu Adapazari ustanovljeno je sljedeće stanje: Inventarizacijom je obuhvaćena je 61 svojta iz 28 porodica. U parku dominiraju kritosjemenjače, među kojima su dvosupnice izrazito zastupljenije nego jednosupnice. S najvećim brojem svojti ističe se porodica Rosaceae. Obzirom na tip habitusa rezultati pokazuju dominaciju stabala, a listopadne svojte su zastupljenije od vazdazelenih. Od 61 zabilježenih svojti, zabilježen je i manji broj kultivara, hibrida i podvrsti.

Donatım park prilično je bogat dendrološkim svojtama, čije drveće i grmlje uglavnom ima izvrsne funkcionalne, estetske i oblikovne karakteristike. Debla stabala su zdrava, pravilno formiranih krošnji, bez gljivičnih infekcija, rak rana i tumora. Parkovna infrastruktura (klupe, spomenici, staze, mostovi, fontane) se nalaze u odličnom stanju. Parku je potrebna umjerena revitalizacija (zamjena starih stabala datulje).

\section{Literatura}

Anić, I. (2009). Uzgajanje šuma II, Interna skripta. Zagreb: Šumarski fakultet Sveučilišta u Zagrebu.

Ata, C. (1995). Silvikültür. Bartin: Zonguldak Karaelmas Üniversitesi Bartın Orman Fakültesi Yayınları, No: 4/3.

Barbarić, M., Raič, A., Karačić, A. (2014). Priručnik iz maslinarstva. Mostar: Federalni agromediteranski zavod Mostar.

Borzan, Ž. (2001). Imenik drveća i grmlja - latinski, hrvatski, engleski i njemački. Zagreb: Hrvatske šume.

Çiçek, E. (2002). Adapazarı-Süleymaniye Subasar Ormanında Meşcere Kuruluşları ve Gerekli Silvikültürel Önlemler. Doktora tezi, İstanbul.

Çiçek, E., Yilmaz, M., (2002). The Importance of Fraxinus angustifolia subsp. Oxycarpa as a Fast Growing Tree for Turkey. In (eds. Ercan M, Diner A, Birler AS, Goulding C, ZoralioÄŁlu T), Proceedings, IUFRO Meeting: Management of Fast Growing Plantations, Div. 4.04.06, 11-13 September 2002, Izmir, Turkey, 192-200.

Çinar, HS., Parlak, NN., Donmez, N. (2018). Climate Friendly Urban Green Areas: Roadside Green Spaces in Sakarya/Turkey. Periodicals of Engineering and Natural Sciences, 6 (2), 159-167.

Çoban, S., Doğanay Yener, S., Bayraktar, S. (2021). Woody plant composition and diversity of urban green spaces in Istanbul, Turkey, Plant Biosystems, 155 (1), 83-91. 
Čurović, Ž., Stešević, D., Čurović, M., Spalević, V. (2003). Autochtonus dendroflora of the parks of Podgorica. Natura Montenegrina, 2, 19-40.

Domac, R. (1994). Flora Hrvatske. Zagreb: Školska knjiga.

Dorbić, B., Šolić, I., Gugić, M., Temim, E., Šarolić, M., Šuste, M. (2014). Inventarizacija voćnih vrsta i ukrasne dendroflore u privatnim vrtovima na području grada Knina. Pomologia Croatica, 20 (1-4), 43-56.

Dorbić, B., Španjol, Ž. (2018). Borovi (Pinus sp.) u hortikulturi i šumarstvu na kršu. Simpozij Poljoprivreda i šumarstvo na kršu mediteransko-submediteranskog istočnojadranskog područja - stanje i perspektive-Posebna izdanja ANUBiH CLXXVI, OPMN 27, Šarić, T., Beus, V. (ur.). Sarajevo: ANUBIH, 13.

Dorbić, B., Temim, E. (2018). Valorizacija dendro elemenata u parkovima i pejsažnim površinama na području Šibensko-kninske županije. Annales-Anali za Istrske in Mediteranske Studije-Series Historia et Sociologia, 28 (1), 167-192

Erhardt, W., Gotz, E., Bodeker, N., Seybold, S. (2002). Zander, Handworterbuch der Pflanzennamen. Stuttgart: Eugen Ulmer.

FAO. Fao-Yearbook, 1995-2004.

Franjić, J., Škvorc, Ž. (2010). Šumsko drveće i grmlje Hrvatske. Zagreb: Šumarski fakultet Sveučilišta u Zagrebu.

Fraxigen. (2005). Ash Species in Europe: Biological Characteristics and Practical Guidelines for Sustainable Use. Oxford: Oxford Forestry Institute, University of Oxford, United Kingdom.

Gedikli, B. (2004). Urbanization and land-use planning in Adapazar1 (Turkey) reconsidered after the 1999 earthquake. Journal of Housing and the Built Environment, 20, 79-91.

Idžojtić, M. (2005). Listopadno drveće i grmlje u zimskom razdoblju. Zagreb: Sveučilište u Zagrebu, Šumarski fakultet.

Idžojtić, M. (2009). Dendrologija-List. Zagreb: Sveučilište u Zagrebu, Šumarski fakultet.

Idžojtić, M. (2013). Dendrologija - cvijet, češer, plod, sjeme. Zagreb: Sveučilište u Zagrebu, Šumarski fakultet

Idžojtić, M. (2013). Dendrologija - cvijet, češer, plod, sjeme. Zagreb: Sveučilište u Zagrebu, Šumarski fakultet. 
Idžojtić, M. (2019). Dendrology: Cones, Flowers, Fruits and Seeds. London, San Diego, Cambridge, Oxford: Elsevier-Academic Press.

Jovanović, B. (1985). Dendrologija. Beograd: Šumarski fakultet, Univerzitet u Beogradu.

Karavla, J. (1997). Parkovni objekti u općini Rijeka. Šumarski list, 121 (3-4), 133-160.

Löki, V., Deák, B., Lukács, AB., Molnár V, A. (2019). Biodiversity potential of burial places - a review on the flora and fauna of cemeteries and churchyards, Global Ecology and Conservation,18, e00614,

Miranović, K. (2006). Maslina (Olea europea L.). Podgorica: Novinsko, izdavačko i grafičko akcionarsko društvo "Pobjeda", Podgorica.

Nikolić, M.D., Radulović, M.D. (2010). Suptropske i tropske voćke. Čačak: Naučno voćarsko društvo Srbije Čačak.

Nikolić, T. (ur.) (2021). Flora Croatica baza podataka / Flora Croatica Database. Botanički zavod s Botaničkim vrtom, Prirodoslovno-matematički fakultet, Sveučilište u Zagrebu. Dostupno na: http://hirc.botanic.hr/fcd.

Panjan, H. (2020). Klimatska osjetljivost poljskog jasena u Republici Hrvatskoj. Diplomski rad, Sveučilište u Zagrebu, Šumarski fakultet.

Potapenko I., Letukhova, V., Klimenko, N. (2020). Ornamental trees and shrubs in green areas of the South-East coast of the Crimea. E35 Web Conf, XIII International Scientific and Practical Conference "State and Prospects for the Development of Agribusiness - INTERAGROMASH 2020", 175, 1-14.

Russell, T. (2003). The world encyclopedia of trees. Lorenz Books.

Sandeva, V., Despot, k., Simovsk1, B., Nikolov, B., Gjenchevski, D. (2013). The main function of plant design of parks and gardens. For. Review, 44, 34-39.

Scaltsoyrannes, A., Rohr, R., Panetsos, K.P., Tsaktsira, M. (1994). Allozyme frequency distributions in five European populations of Black pine (Pinus nigra Arnold). Silvae Genetica, 43, 20-30.

Schwarz, O. (1938). Über die Systematik und Nomenklatur der Europäischen Schwarzkiefern. Notizblatt des Bot. Garten zu Berlin Dahlem, 8 (117), 226-243.

SBB, "Sakarya Municipality 2015-2019 Strategic Plan", 2015.

Šilić, Č. (1990). Ukrasno drveće i grmlje. Sarajevo: Svjetlost.

Šilić, Č. (2005). Atlas dendroflore (drveće i grmlje) Bosne i Hercegovine. Čitluk: Matica hrvatska. 
E. Delić, B. Dorbić, Alisa Adžemović / Dendroflora Donatim parka u Adapazariju/Sakarija Republika Turska / Glasilo Future (2021) 4 (2-3) 01-15

Šolić, P. (1974). Prilog poznavanju nesamonikle dendrolore parkova i nasada Mostara i okoline, Horikultura, Split.

Tafra, D., Pandža, M., Milović, M. (2012). Dendroflora Omıša. Šumarski list, 136 (11-12), 605-616.

Tolun, A.A., Velioglu, E., Çengel, B.N., Kaya, Z. (2000). Genetic Structure of Black Pine (Pinus nigra ARNOLD subspecies pallasiana) Populations Sampled from the Bolkar Mountains. Silvae Genetica 49(3), 113-119.

Tutin, T.G., Heywood, V.T., Burges, N.A., Moore, D.M., Valentine, D.H., Walters, S.M., Webb, D. A. (eds.). (1964-1980). Flora europea 1-5. Cambridge: Cambridge University Press.

UNDP,“"SustainableDevelopmentGoals",

http://www.undp.org/content/undp/en/home/sustainabledevelopment-goals.html, Access date: 12.01 .2018

Vidaković, M. (1993). Četinjače-morfologija i varijabilnost. Zagreb: GZH i "Hrvatske šume", Zagreb. Vidaković, M., Franjić, J. (2004). Golosjemenjače. Zagreb: Sveučilište u Zagrebu, Šumarski fakultet. Wallander, E. (2013). Systematics and floral evolution in Fraxinus (Oleaceae). Belgische Dendrologie, 2012, 38-58.

Walters, S.M., Brady, A., Brickell, C.D., Cullen, J., Green, P.S., Lewis, J., Matthews, V.A., Webb, D. A., Yeo, P.F., Alexander, J.C.M. (eds.). (1984-1986). The European Garden Flora, I-II. Cambridge: Cambridge University Press.

Walters, S.M., Brady, A., Brickell, C.D., Cullen, J., Green, P.S., Lewis, J., Matthews, V.A., Webb, D. A., Yeo, P.F., Alexander, J.C.M. (eds.). (1989). The European Garden Flora, III. Cambridge: Cambridge University Press.

https://www.sakarya.bel.tr/tr/Haber/donatim-park-yeni-yuzune-kavustu/8700 (Pristupljeno: 10.05.2021).

https://www.sozcu.com.tr/hayatim/seyahat/sakaryanin-incisi-donatim-park/ (Pristupljeno: 10.05.2021).

Primljeno: 04. svibnja 2021. godine

Prihvaćeno: 30 lipnja 2021. godine
Received: May 04, 2021

Accepted: Jun 30, 2021 